\title{
Role of Calretinin in Determining the Aganglionic Segment in Hirschsprung's Disease
} Onur Ceylan ${ }^{\oplus}$
Özgür Çağlar $\odot$

\section{Hirschsprung Hastalığında Aganglionik Segmentin Belirlenmesinde Kalretinin'in Rolü}

\begin{abstract}
Objective: This study aims to determine the presence, shape, and value of immunoreactivity of calretinin in ganglionic and aganglionic colon samples in Hirschsprung's Disease (HSCR).

Method: This study included the ganglion positive and negative intestinal tissue materials of 63 patients admitted to the hospital with the prediagnosis of HSCR. Calretinin immunomarker was applied to the materials. The cases were divided into three groups as strongly positive, weakly positive and negative for calretinin. Staining differences between ganglionic and aganglionic tissue samples were examined. Results: In all ganglionic biopsy materials, calretinin was seen to be strongly positive in the submucosal and myenteric plexuses. Calretinin was evaluated as negative in 60 of aganglionic biopsy materials whereas it was found to be weakly cytoplasmic positive in three cases. A significant difference was observed between the positive immunoreactivity of calretinin in the aganglionic and ganglionic segments $(p<0.001)$. Rates of sensitivity, specificity, accuracy, positive, and negative predictive values were found to be $100 \%$, $94.44 \%, 97.14 \%, 94.44 \%$, and $100 \%$, respectively.

Conclusion: Calretinin, which has high sensitivity and specificity, is extremely useful in determining ganglionic and aganglionic segments. We believe that calretinin can provide a definitive diagnosis with a single immunohistochemical study and H\&E section since its interpretation is much easier compared to hematoxylin-eosin (H\&E). Thus, it is extremely important in terms of reducing excessive serial sectioning, the need for immunohistochemical assay and re-biopsy.
\end{abstract}

Keywords: Hirschsprung's disease, calretinin, immunhistochemical assay

öz

Amaç: Çalışmamızın amacı Hirschsprung Hastalığında $(\mathrm{HH})$ gangliyonik ve agangliyonik kolon örneklerinde kalretininin immünreaktivitesinin varlığını, şeklini ve değerini belirlemektir.

Yöntem: HH ön tanısı ile gelen 63 olgunun gangliyon pozitif ve negatif bağırsak dokusu tanısı alan materyalleri çalışmaya dâhil edilip kalretininin immünbelirteci uygulandı. Kalretinin için vakalar kuvvetli pozitif, zayıf pozitif ve negatif olarak üç gruba ayrıldı. Gangliyon içeren doku örnekleri ile gangliyon içermeyen doku örnekleri arasındaki boyanma farklılıkları incelendi.

Bulgular: Gangliyon içeren biyopsi materyallerinin tamamında submukozal ve miyenterik pleksuslardaki gangliyonlarda kalretinin kuvvetli pozitif olarak izlendi. Gangliyon içermeyen biyopsilerin ise 60'ında negatif, 3'ünde zayıf stoplazmik pozitif olarak değerlendirildi. Agangliyonik ve gangliyonik segmentlerde kalretinin pozitif immünreaktivitesi arasında anlamlı bir farklıık izlendi $(p<0.001)$. Kalretinin için sensitivite, spesifisite, doğruluk, pozitif prediktif değer ve negatif prediktif değer oranları sırasıyla \%100, \%94,44, $\% 97,14, \% 94,44$ ve $\% 100$ olarak bulundu.

Sonuç: Gangliyonik ve aganglyionik segmentlerin belirlenmesinde yüksek sensitivite ve spesifisiteye sahip olan kalretinin son derece yararlıdır. Kalretininin hemotoksilen-eozine (H\&E) kıyasla yorumlaması çok daha kolay olduğu için tek bir immünhistokimyasal çalışma ve H\&E kesit ile kesin tanı koydurucu özellikte olduğunu düşünmekteyiz. Bu yüzden aşırı seri kesit, immünhistokimyasal çalışma gereksinimi ve tekrar biyopsi alınması gibi durumları azaltması açısından da son derece önemlidir.

Anahtar kelimeler: Hirschsprung hastalığı, kalretinin, immünhistokimyasal çalışma
Received/Geliş: 10.04 .2020

Accepted/Kabul: 18.04 .2020

Published Online/Online Yayın: 31.08.2020

Onur Ceylan Atatürk Üniversitesi Eğitim ve Araştırma Hastanesi Patoloji Anabilim Dalı, Erzurum - Türkiye dr.onurceylan@gmail.com ORCID: 0000-0001-7025-0521

Özgür Çağlar 0000-0003-4000-4308 Atatürk Üniversitesi Tıp Fakültesi, Çocuk Cerrahisi Anabilim Dalı, Erzurum, Türkiye 


\section{INTRODUCTION}

Hirschsprung's disease (HSCR) is a disorder characterized by the absence of ganglion cells in submucosal and myenteric plexus in the distal colon in general, with an incidence of one in 5.000 births. Although aganglionic areas are often localized in the rectum and rectosigmoid region, a part of the entire colon and small intestine has been reported to be involved ${ }^{(1,2)}$. Therefore, it is of great importance to identify the aganglionic areas pathologically to determine the surgical margins ${ }^{(3)}$. The number of ganglion cells is as significant as the morphological features of the ganglion cells, the number of nerves, and cells of Cajal for the surgical procedure. Histopathological examination is performed with hematoxylin-eosin (H\&E) staining in the first stage. It may be difficult to differentiate immature ganglion cells from lymphocytes, stromal cells, and endothelial cells because they are not widely cytoplasmic. Therefore, immunohistochemical assays are needed in cases where H\&E staining is not sufficient ${ }^{(4)}$.

Calretinin is a vitamin D-dependent protein associated with the calcium signaling mechanism that plays a role in the regulation and maintenance of the central nervous system ${ }^{(5)}$. Barshack et al. ${ }^{(6)}$ were the first authors reporting that expression of calretinin was not observed in aganglionic areas in HSCR, but it was observed in ganglionic areas. In recent years, there have been different studies reporting that calretinin is a beneficial marker in showing ganglia in $\mathrm{HSCR}$, however, the number of these studies is limited and calretinin is used less frequently to determine the presence of ganglion in routine practice ${ }^{(7)}$. This study aimed to determine the presence, shape, and value of immunoreactivity of calretinin in ganglionic and aganglionic colon samples in HSCR and to compare calretinin with older methods (H\&E, S100) used to identify ganglionic colon samples.

\section{MATERIALS and METHODS}

This study included ganglion positive and negative intestinal tissue materials of 63 patients who were admitted to the hospital with a pre-diagnosis of HSCR between January 2010 and January 2019. Clinical information such as gender and age of the patients were obtained from the information system of our hospital. Biopsy materials of the cases were analyzed retrospectively. Tissues were cut into 4-micron sections and placed on charged slides. After incubating at 70 degrees for 15 minutes, the tissues were placed in an automatic immunohistochemical staining device (Ventana Roche, USA). Tissues in the device were treated with ULTRA Cell Conditioning Solution, hydrogen peroxidase, calretinin antibodies (Nova Castra, Leica, Newcastle, United Kingdom) after being subjected to deparaffinization and dehydration, respectively. Hematoxylin-eosin (H\&E) and immunohistochemical study preparations for each case were re-evaluated were evaluated by 2 different pathologists.

The cases were divided into three groups as strongly positive, weakly positive and negative for calretinin (Figure 1, 2, and 3). The differences between the materials showing the presence of ganglions with H\&E staining and clinically specified as ganglionic segment and aganglionic materials were analyzed statistically.

The study was approved by the Local Ethics Committee (B.30.2.ATA.0.01.00/47).

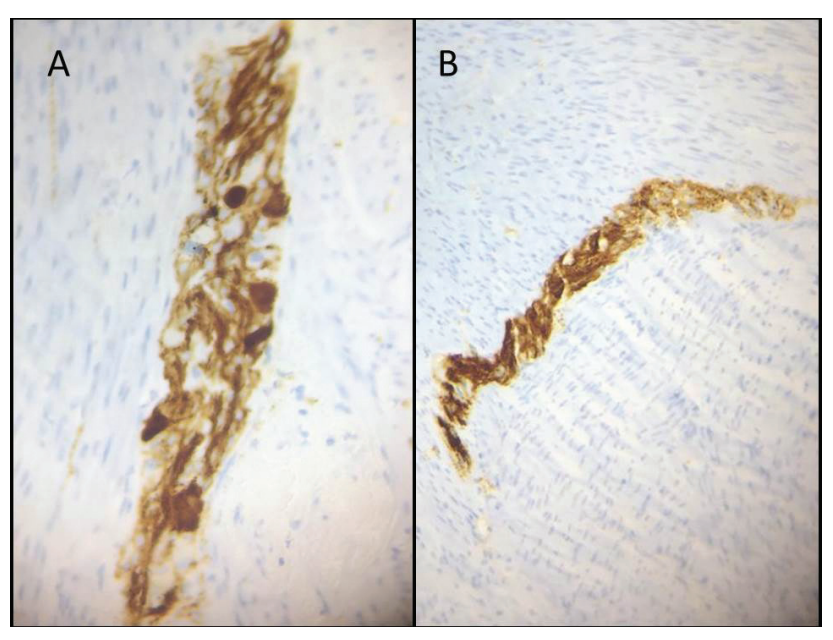

Figure 1. Calretinin immunstaining of strong positivity in ganglion and intrinsic nerve fibers (A/B). 


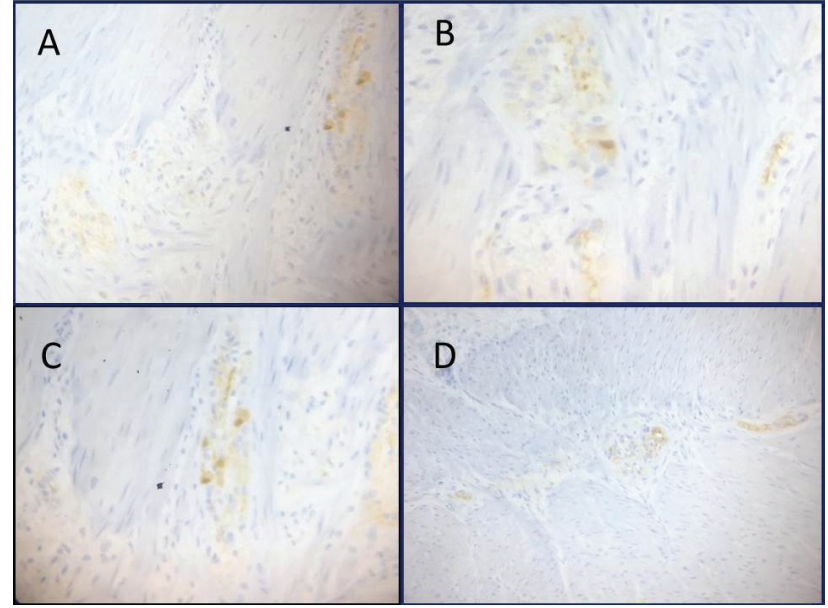

Figure 2. Weak cytoplasmic calretinin immunstaining (A/B/C/D).

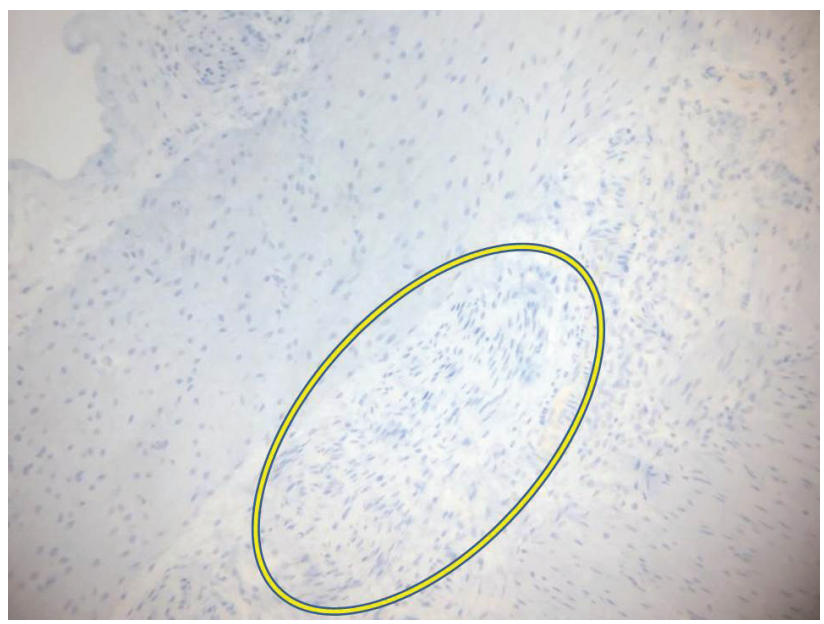

Figure 3. Negative calretinin immunstaining of hypertrophic nerve fiber (yellow circle).

\section{Statistical Analysis}

Statistical analyzes were performed using Medcalc statistical software (MedCalc ver.14, Ostend, Belgium). The normality distribution was evaluated using D'Agostino-Pearson test. Mann-Whitney U test was used to compare the nonparametric data of the two groups. Sensitivity, specificity, positive, and negative predictive value and accuracy rate were calculated for the validity of ganglion- positive andnegative results. The statistical power of the new test to make a distinction between ganglion-positive and negative cases was determined. A $p$ value of $<0.05$ was considered statistically significant.

\section{RESULTS}

The mean age of 63 patients was 14 months. There was no significant difference between the genders in terms of the mean age (p:0.2). Of the cases, 15 were female and 48 were males, with a male-to-female ratio of 3,2/1.

Biopsy materials belonging to both ganglionic and aganglionic segments were available in all 63 cases. Calretinin staining was observed as strong cytoplasmic and nuclear positive in all submucosal and myenteric plexuses in the segments proved to be ganglion positive via H\&E staining. Calretinin staining was found to be negative in 60 biopsy materials and surgical operation materials proved to be positive for the aganglionic segment after H\&E staining and biopsy and as weak cytoplasmic positive in three patients. A significant difference was observed between the positive immunoreactivity of calretinin in the aganglionic and ganglionic segments $(p<0.001)$. Rates of sensitivity, specificity, accuracy, positive and negative predictive values were found to be $100 \%$, $94.44 \%, 97.14 \%, 94.44 \%$, and $100 \%$, respectively. No positive immunoreactivity was observed in ganglionpositive areas with S100 whereas there was a positive immunoreactivity in hypertrophic nerve fibers in ganglion negative areas in all of the peripheral nerve fibers around the ganglia. Since S100 did not show positive immunoreactivity in ganglion cells but only in nerve fibers, rates of sensitivity, specificity, accuracy, positive and negative predictive values were calculated for the S100 and ganglion-free nerve fibers and were found as follows: $\% 100, \% 50, \% 66,67$, $\% 50, \% 100$.

Table 1. Comparisons of immunstaining between groups.

\begin{tabular}{|c|c|c|c|c|c|}
\hline & \multicolumn{2}{|c|}{$\begin{array}{l}\text { Aganglionic Segment } \\
\text { (N:63) }\end{array}$} & \multicolumn{2}{|c|}{$\begin{array}{c}\text { Ganglionic } \\
\text { Segment (N:63) }\end{array}$} & \multirow[b]{2}{*}{$\mathbf{p}^{\mathbf{a}}$} \\
\hline & $\begin{array}{l}\text { Intrinsic } \\
\text { Nerve } \\
\text { Fiber }\end{array}$ & $\begin{array}{c}\text { Hypertrophic } \\
\text { Nerve } \\
\text { Fiber }\end{array}$ & $\begin{array}{l}\text { Ganglion } \\
\text { Cells }\end{array}$ & $\begin{array}{c}\text { Intrinsic } \\
\text { Nerve } \\
\text { Fiber }\end{array}$ & \\
\hline Calretinin & 3 & - & 63 & 63 & $<0.001$ \\
\hline S100 & 63 & 63 & - & 63 & $<0.001$ \\
\hline
\end{tabular}

Values are expressed as a number.

${ }^{a}$ Chi Square test 
Whereas 3 of the aganglionic biopsy materials with calretinin showed weak immunoreactivity in intrinsic nerve fibers, and any hypertrophic nerve fibers were not observed. Strongly positive immunoreactivity was observed with calretinin in both ganglion cells and intrinsic nerve fibers in all ganglioncontaining biopsy materials (Table 1 ).

\section{DISCUSSION}

Hirschsprung's disease, also known as congenital aganglionic megacolon, stands out with the absence of ganglion cells in submucosal and myenteric plexuses in the distal gastrointestinal tract and increasing number of hypertrophic nerve bundles ${ }^{(8)}$. The maleto-female ratio is $3-4 / 1{ }^{(9)}$. Forty-eight male, and 15 female patients were included in the study (male/ female: 3,2/1). Similar to other studies in the literature, the incidence has been found to be higher in males in our study.

In many centers, more than $50 \mathrm{H} \& \mathrm{E}$ stained serial sections are requested to prove the presence or absence of ganglion cells, resulting in substantial tissue loss and increased workload ${ }^{(10)}$. There are studies reporting that the calretinin is an extremely useful marker for solving such problems and making a definitive diagnosis when H\&E staining is not sufficient ${ }^{(4)}$.

Calretinin, which has a significant role in the regulation of neuronal activity, shows positive immunoreactivity in the nerve structures in lamina propria, muscularis mucosa, and superficial submucosa, as well as ganglion cells in the nerve plexus. In aganglionic segments, any positive immunoreactivity was not observed in hypertrophic nerve fibers ${ }^{(5)}$. In our study, strong calretinin immunoreactivity was observed in all ganglionic segments whereas any immunoreactivity was not observed in almost all aganglionic segments. There was a significant difference in terms of aganglionic and ganglionic areas. Positive results were obtained in determining the presence of ganglion with calretinin and high specificity, sensitivity and accuracy values were observed. Other studies in the literature have reported similar results. Jeong et al. ${ }^{(11)}$ found calretinin negativity in all 34 aganglionic colon biopsies and nine of 61 ganglionic biopsies and reported the specificity and sensitivity of calretinin as $85.2 \%$ and $100 \%$, respectively. Hiradfar et al. ${ }^{(12)}$ reported rates of sensitivity, specificity, positive and negative predictive values as $93.3 \%, 100 \%, 100 \%$, and $93.8 \%$, respectively. In a study by Barshack et al. (6) calretinin staining has been reported to be negative in all aganglionic areas in HSCR cases and positive both in ganglia and nerve fibers in ganglionic segments.

In all of our cases, no positive immunoreactivity was observed in ganglion- positive areas with S100 whereas there was a positive immunoreactivity in hypertrophic nerve fibers in ganglion negative areas in all of the peripheral nerve fibers around the ganglia. Jiang et al. ${ }^{(13)}$ also achieved results similar to ours and reported that $\mathrm{S} 100$ is useful in determining the aganglionic segment in HSCR when used with a method other than calretinin. They reported that in the ganglionic segments they had negative immunoreactivity in ganglion cells and positive immunoreactivity in the glial cells surrounding them and intrinsic nerve fibers. Also they stated that they observed positive immunoreactivity in hypertrophic nerve fibers in aganglionic segments. In this way, they argued that the $\mathrm{S} 100$ would be useful marker both in identifying hypertrophic nerve fibers and in detecting negatively stained ganglion cells surrounded by positive staining. Considering the fact that hypertrophic nerve fibers are present in aganglionic areas, we believe that the S100 can be useful in diagnosis indirectly, but when compared with calretinin, more effective results can be obtained with calretinin directly.

Tran et al. ${ }^{(14)}$ suggested that calretinin was more practical to determine the aganglionic segment in HSCR and that calretinin should be preferred first. In a study by Mukhopadhyay et al. ${ }^{(15)}$ with a larger patient group, calretinin was emphasized to be a very useful biomarker to distinguish HSCR from diseases with similar symptoms such as pseudo-HSCR, visceral neuropathy, and myopathy compared to immunomarkers such as cholinergic markers, neuropeptides, and synaptic markers.

The results obtained in the present study are compatible with the studies in the literature. 
Calretinin H\&E has been interpreted very easily in all segments proven to be ganglion positive and has been found to be positive in ganglia in both submucosal and myenteric plexuses. Calretinin was evaluated to be negative in 60 of the biopsy materials and surgical operation materials proved to be positive for the aganglionic segment after H\&E and biopsy. When three cases, where ganglion cells were not detected and calretinin immunoreactivity was observed, were examined, small intrinsic nerve fibers were observed to be stained with calretinin. On the other hand, no calretinin immunoreactivity was observed in any of the hypertrophic nerve fibers. Similar to our study, Jiang et al. ${ }^{(13)}$ reported calretinin staining in aganglionic intrinsic nerve fibers in a few cases. Most of the studies in the literature reported that calretinin staining occurred only in ganglionic plexuses. In light of all these data, we believe that the calretinin negativity alone is an effective method in determining the aganglionic segment and in areas where positive immunoreactivity is recorded, it is necessary to make a decision in combination with H\&E to eliminate false positives.

When we examined aganglionic cases showing a positive calretinin immunoreactivity from a different perspective, a weak calretinin staining pattern was observed in small intrinsic nerve fibers in all of these cases. Staining in ganglionic nerve plexuses was strongly cytoplasmic and nuclear. Muller et al. (16) reported that the weak calretinin staining was a variant staining pattern and thus, staining was seen in the transitional zone in the HSCR. When these three cases were examined prospectively, a clinicalpathological incompatibility was observed with the pathological diagnosis of ganglion positivity. Similar to the study by Muller et al., ${ }^{(16)}$ we believe that weak staining can be seen in the transition zones and that only strong calretinin staining can be significant in determining the presence of a ganglion. We suggest that this issue should be investigated further since there is a limited number of studies on this subject in the literature.

In conclusion, immature ganglion cells may be confused with cells such as lymphocytes, endothelial cells, and stromal cells since they do not resemble mature ganglion cells and therefore, false positive results can be obtained with H\&E. Calretinin, which has high sensitivity and specificity, is extremely useful in solving such problems. Furthermore, we believe that calretinin can provide a definitive diagnosis with a single immunohistochemical study and H\&E section since its interpretation is much easier compared to NSE, S100, and H\&E. Therefore, it is extremely important in terms of reducing excessive $\mathrm{H} \& \mathrm{E}$ serial sectioning, the need for immunohistochemical assay and re-biopsy.

The limitation of our study is the limited number of cases. We believe that studies with a larger patient population will increase the reliability of our findings.

Ethics Committee Approval: Atatürk University Faculty of Medicine Clinical Research Ethics Committee approval was received (16.01.2020/ B.30.2.ATA.0.01.00/47).

Conflict of Interest: The authors declared no potential conflicts of interest with respect to the research, authorship and/or publication of this article.

Funding: The authors received no financial support for the research, authorship, and/or publication of this article.

Informed Consent: Written informed consents were obtained from the adolescents and their parents.

\section{REFERENCES}

1. Kapur RP, Reed RC, Finn LS, Patterson K, Johanson J, Rutledge JC. Calretinin immunohistochemistry versus acetylcholinesterase histochemistry in the evaluation of suction rectal biopsies for Hirschsprung Disease. Pediatric and developmental pathology : the official journal of the Society for Pediatric Pathology and the Paediatric Pathology Society. 2009;12(1):6-15. https://doi.org/10.2350/08-02-0424.1

2. Bachmann L, Besendorfer M, Carbon R, Lux P, Agaimy A, Hartmann A, et al. Immunohistochemical panel for the diagnosis of Hirschsprung's disease using antibodies to MAP2, calretinin, GLUT1 and S100. Histopathology. 2015;66(6):82435.

https://doi.org/10.1111/his.12527

3. Knowles CH, De Giorgio R, Kapur RP, Bruder E, Farrugia G, Geboes K, et al. Gastrointestinal neuromuscular pathology: guidelines for histological techniques and reporting on behalf of the Gastro 2009 International Working Group. Acta Neuropathologica. 2009;118(2):271-301. https://doi.org/10.1007/s00401-009-0527-y 
4. Cinel L, Ceyran B, Gucluer B. Calretinin immunohistochemistry for the diagnosis of Hirschprung disease in rectal biopsies. Pathology, Research and Practice. 2015;211(1):50-4.

https://doi.org/10.1016/j.prp.2014.08.012

5. Guinard-Samuel V, Bonnard A, De Lagausie P, PhilippeChomette P, Alberti C, El Ghoneimi A, et al. Calretinin immunohistochemistry: a simple and efficient tool to diagnose Hirschsprung disease. Modern pathology : an official journal of the United States and Canadian Academy of Pathology, Inc. 2009;22(10):1379-84. https://doi.org/10.1038/modpathol.2009.110

6. Barshack I, Fridman E, Goldberg I, Chowers Y, Kopolovic J. The loss of calretinin expression indicates aganglionosis in Hirschsprung's disease. Journal of Clinical Pathology. 2004;57(7):712-6. https://doi.org/10.1136/jcp.2004.016030

7. Anbardar $\mathrm{MH}$, Geramizadeh B, Foroutan HR. Evaluation of Calretinin as a New Marker in the Diagnosis of Hirschsprung Disease. Iranian Journal of Pediatrics. 2015;25(2):e367. https://doi.org/10.5812/ijp.367

8. Meier-Ruge W, Bruder E. Histopathological diagnosis and differential diagnosis of Hirschsprung's disease. Hirschsprung's disease and allied disorders: Springer; 2008. p. 185-97. https://doi.org/10.1007/978-3-540-33935-9_13

9. Qualman SJ, Jaffe R, Bove KE, Monforte-Munoz H. Diagnosis of hirschsprung disease using the rectal biopsy: multiinstitutional survey. Pediatric and developmental pathology: the official journal of the Society for Pediatric Pathology and the Paediatric Pathology Society. 1999;2(6):588-96. https://doi.org/10.1007/s100249900167

10. Kapur RP, Raess PW, Hwang S, Winter C. Choline Transporter Immunohistochemistry: An Effective Substitute for Acetylcholinesterase Histochemistry to Diagnose Hirschsprung Disease With Formalin-fixed Paraffinembedded Rectal Biopsies. Pediatric and developmental pathology : the official journal of the Society for Pediatric
Pathology and the Paediatric Pathology Society. 2017;20(4):308-20.

https://doi.org/10.1177/1093526617697060

11. Jeong $H$, Jung HR, Hwang I, Kwon SY, Choe M, Kang YN, et al. Diagnostic Accuracy of Combined Acetylcholinesterase Histochemistry and Calretinin Immunohistochemistry of Rectal Biopsy Specimens in Hirschsprung's Disease. International Journal of Surgical Pathology. 2018;26(6):50713.

https://doi.org/10.1177/1066896918761235

12. Hiradfar M, Sharifi N, Khajedaluee M, Zabolinejad N, Taraz Jamshidi S. Calretinin Immunohistochemistery: An Aid in the Diagnosis of Hirschsprung's Disease. Iranian Journal of Basic Medical Sciences. 2012;15(5):1053-9.

13. Jiang $M$, Li K, Li S, Yang L, Yang D, Zhang $X$, et al. Calretinin, S100 and protein gene product 9.5 immunostaining of rectal suction biopsies in the diagnosis of Hirschsprung' disease. American Journal of Translational Research. 2016;8(7):315968.

14. Tran VQ, Truong DQ, Goyens P, Steyaert H. Rectal suction biopsy with calretinin immunohistochemistry in patients suspected with residual aganglionosis after operation for Hirschsprung disease. Journal of Pediatric Surgery. 2017;52(10):1597-601. https://doi.org/10.1016/j.jpedsurg.2017.02.016

15. Mukhopadhyay B, Sengupta M, Das C, Mukhopadhyay M, Barman S, Mukhopadhyay B. Immunohistochemistry-based comparative study in detection of Hirschsprung's disease in infants in a Tertiary Care Center. Journal of Laboratory Physicians. 2017;9(2):76-80. https://doi.org/10.4103/0974-2727.199623

16. Muller CO, Hobeika C, Montalva L, Berrebi D, Bonnard A. Calretinin Variant in Hirschsprung Disease: Pretransitional Sign and Surgical Planning. European journal of pediatric surgery : official journal of Austrian Association of Pediatric Surgery [etal] =Zeitschriftfur Kinderchirurgie. 2016;26(5):44953.

https://doi.org/10.1055/s-0035-1566106 